\title{
3
}

\section{A Century of Social Alternatives in a Japanese Mountain Community}

\author{
Tessa Morris-Suzuki
}

\section{The Storyteller and the Stories}

The village of Motai in Nagano Prefecture, Japan, is about 2,000 kilometres away from Bishan in China, where Ou Ning and his fellow residents have developed the grassroots social visions described in Chapter Two. As far as I know, these two places have no direct connection with one another. Both suffer from the problems that assail so many small rural communities throughout East Asia and beyond-ageing populations, limited employment opportunities-but other than that, they are not particularly alike. Bishan, which once lay at the heart of the prosperous mercantile Huizhou region, is a place of old stone and brick buildings, some of which are now lovingly being restored. Motai and its slightly larger neighbouring town of Mochizuki-both now merged into the artificial Saku City-were once post-towns on the Nakasendō, one of the great roads that ran like arteries across the landscape of premodern Japan. Their old buildings are wooden-fronted; their warehouses have crumbling earthen walls.

But these small places in Japan and China are like springs of water that, although far apart, are fed by the same network of underground watercourses-deep, invisible, complicated watercourses running quietly under the familiar landscape of East Asian history. On the surface sit 
China, the emerging superpower whose rampant capitalism has signally failed to give birth to liberalism and democracy, and Japan, whose increasingly assertive nationalist government struggles to extract the nation from the economic quagmire of two-and-a-half 'lost decades'. But in Bishan and the Mochizuki area, dreams are being pursued that (in anthropologist Tom Cliffs words) 'run perpendicular' to the state dreams for both countries. ${ }^{1}$ These little local dreams have similarities that are not coincidental: they spring from the same fluid and meandering current of political and social ideas that has been flowing under the surface of East Asia for at least a century.

You can hear the similarities echoing in the words that fly about in the community halls of the two places_-words like 'autonomy', 'mutual aid', 'endogenous development', 'cooperatives', 'counter-urbanisation'. You can also see and feel similarities in the symbolic sites and events that make the dreams tangible. The mixture of tradition and critical modernity enacted in the spectacle of Bishan's Harvestival (see Chapter Two), for example, is mirrored on a smaller scale by an event in Motai that I attended on a warm spring day in 2014.

This event was the launch of the year's new saké (rice wine 酒), celebrated with speeches and taiko (太鼓) drumming in the courtyard of an ancient brewery under a cloudless sky. The brewery, founded in the 17 th century, stands at the heart of the village. A member of the local assembly arrived to offer his congratulations. Young and old tried their hand at pounding rice into mochi in a wooden vat whose surface wore the patina of generations of use. The tables were laden with home-grown and homemade delicacies. It seemed like a perfect evocation of 'traditional Japan'.

1 Tom Cliff, 'Pastoral Dreams: Bishan Village, Anhui, China'. On the website 'Survival Politics: ARC Laureate Project "Informal Life Politics"'. survivalpolitics.org/case-study/china-2/pastoraldreams-bishan-village-anhui-china/. 


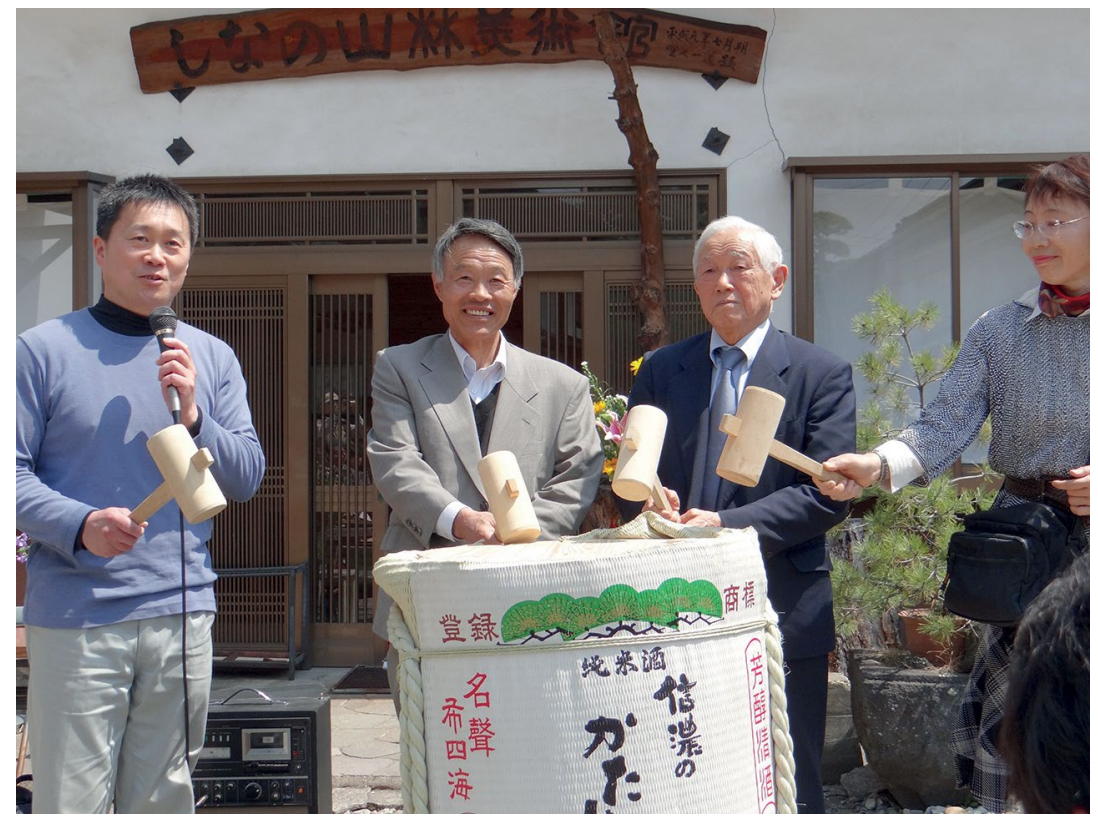

Figure 2: The Motai saké festival.

Source: Tessa Morris-Suzuki.

But after the familiar phrases of greeting, the speeches took a less predictable turn. The eminent environmental economist Miyamoto Kenichi was loudly applauded as he condemned the government's heavyhanded top-down development projects, and drew connections between local social problems and the sufferings of the Okinawan people in their struggle against US military bases. Friends and neighbours in the crowd swapped information on the unending aftermath of the Fukushima disaster and a forthcoming demonstration against nuclear power; and on our way home, we dropped off at the nearby house of an elderly resident, to be presented with the libretto of an opera that he and his friends had composed, and regularly perform, in Esperanto. This is not eccentricity or defiance of tradition. It is an alternative quiet, semi-visible tradition that is too often obscured by stereotypes of rural conservatism and Japanese group consciousness. The brand of saké being celebrated at this annual festival in Motai is called Kataribe かたりべ, which means 'storyteller', and although the brand itself is only quarter of a century old, the stories it tells have origins that go back 100 years or more. 
The long-neglected context from which these stories emerge has recently begun to be rediscovered by historians. In Chapter One of this book, Sho Konishi explores the strong current of anti-war cooperatist thought that emerged in early 20th-century Japan, with powerful connections to simultaneous currents in Russia. He also draws attention to the remarkable prewar Japanese enthusiasm for the study of Esperanto, and the broader internationalism in which this enthusiasm was embedded. ${ }^{2}$ Robert Stolz's book Bad Water reinterprets the early environmentalism of the Meiji era anti-pollution activist Tanaka Shōzō (1841-1913), and shows how Tanaka's vision of 'natural democracy' continued to inspire social thinkers such as Ishikawa Sanshirō (1876-1956, an anarchist and Esperantist, also discussed by Konishi in Chapter One). ${ }^{3}$ From a somewhat different perspective, Tetsuo Najita's study Ordinary Economies in Japan emphasises the significant role that credit and producer cooperatives played in modern Japanese development, and explores the distinctive visions of economic life that sustained cooperativism, particularly in rural Japan. ${ }^{4}$

Such ideas span a wide political spectrum and defy simple categorisation. They stretch from the radical political thought of anarchists like Ōsugi Sakae (1885-1923) to the more romantic idealism of the White Birch Group (Shirakaba-ha 白樺派), who espoused humanism, social utopianism and the folk arts movement. Central figures in this group included novelists Arishima Takeo (1878-1923) and Shiga Naoya (1883-71, also a disciple of Tanaka Shōzō), Mingei (folk arts 民芸) movement founder Yanagi Sōetsu (1889-1961), and Mushanakōji Saneatsu (1885-1976). From 1918 onward, Mushanakōji put his social visions into action in the communal life of the utopian 'New Villages' (Atarashiki Mura 新しき村), which he established in Kyushu and Saitama Prefecture, and which also influenced the Chinese tradition of rural reconstruction that finds contemporary expression in Bishan.

These social visionaries perceived human life as deeply enmeshed in the wider flows of nature. They did not reject the market per se, but expressed profound concern at the relentless pursuit of economic might and commercial profit in industrialising Japan. They valued the farmer's

2 See also Sho Konishi, Anarchist Modernity: Cooperatism and Japanese-Russian Intellectual Relations in Modern Japan (Cambridge, Mass.: Harvard University Asia Center, 2013), particularly Chapter 5.

3 Robert Stolz, Bad Water: Nature, Pollution and Politics in Japan, 1870-1950 (Durham, NC: Duke University Press, 2014).

4 Tetsuo Najita, Ordinary Economies in Japan: A Historical Perspective, 1750-1950 (Berkeley and London: University of California Press, 2009). 
connections to the soil, and dreamed of the re-creation of egalitarian small-scale communities, but they also embraced a form of modern cosmopolitanism symbolised by their enthusiasm for Esperanto. Their heroes (as we have seen) included Lev Tolstoy, William Morris, Peter Kropotkin and the French entomologist Jean-Henri Fabre. ${ }^{5}$

The cooperativist thought discussed by Najita, on the other hand, was more often paternalistic and socially conservative, but in certain moments and places it too embodied ideas of self-help that overlapped with the anarchist radicalism explored by Konishi and Stolz. As Konishi shows in Chapter One, during the 1910s and 1920s experiments in cooperative farming as well as cooperative 'People's Hospitals' and 'People's Cafeterias' flourished in various parts of Japan. Political alliances, indeed, were fluid and ambiguous. Some of those linked to Tanaka Shōzō and the White Birch Group became active in postwar socialist politics, but others, such as Yanagi Sōetsu, were later to be condemned for advocating ideas that all too easily resonated with the imperialist ideologies of wartime Japan. ${ }^{6}$ During the Cold War era, the fading visions of these loosely connected groups tended to be dismissed by orthodox Marxists as failed bourgeois idealism, and by advocates of capitalist high growth as muddle-headed if not actively subversive.

This chapter revisits those views by exploring how some of these early 20th-century critical ideas survived and interacted with postwar social and environmental thought, and how they continue to form a vibrant part of local life in corners of rural Japan to the present day. To trace the history of these alternative traditions, I focus on a region of a few hundred square kilometres in the very heart of the island of Honshü-the area largely occupied (in administrative terms) by the present-day city of Saku, Nagano Prefecture.

5 See Chapter One of this volume; also Konishi, Anarchist Modernity, 297-300.

6 See for example Yuko Kikuchi, Japanese Modernisation and Mingei Theory: Cultural Nationalism and Oriental Orientalism (London: Routledge Curzon, 2004); Noriko Aso, 'Mediating the Masses: Yanagi Sōetsu and Fascism', in Alan Tansman ed., The Culture of Japanese Fascism (Durham, NC: Duke University Press, 2010), 138-54. 


\section{A Place in the Mountains}

The images conjured up by the word 'city' are likely to mislead. Saku, extending across a wide plateau from Mount Tateshina in the southwest towards the foothills of Mount Asama in the northeast, is a city only the most artificial sense of the word. Its population of around 100,000 lives scattered over an area of more than 400 square kilometres. ${ }^{7}$ Although the expansion of the highway network in the 1980s and 1990s and the coming of the Shinkansen super-express in 1997 generated a sprawl of shops, houses and factories in the centre of the plateau, many of Saku's inhabitants still live in the towns and villages-Asama, Nozawa, Usuda, Mochizuki, Motai and others-which were strung together to form the city (sometimes in the face of strenuous resistance) during Japan's local government amalgamations of 1961 and 2005. Each of these communities retains its distinct history and sense of identity, and each in turn is a mosaic of smaller hamlets with their own stories to tell. Some, like Motai, found themselves unceremoniously bisected by the new city boundaries: one end of Motai's main street lies in Saku City while the other is in the neighbouring town of Tateshina.

The valleys of Saku, with their volcanic soil and multitude of mountain streams, are good rice-growing and saké-brewing country, but the winters are bitterly cold, and the higher mountain slopes produce hard-won crops of vegetables and buckwheat. The area could be seen as a microcosm of rural Japan. Its population is ageing, ${ }^{8}$ and enthusiastic schemes to attract investment and tourism fight a constant battle against a lingering pall of economic stagnation. The forces of globalisation stir unease in these valleys, and the road sides are dotted here and there with placards protesting the free-trade Trans-Pacific Partnership (TPP).

The history of popular social thought that I trace here is not (of course) confined to Saku City and its surroundings. It has appeared, disappeared and reappeared in many parts of Japan. Both Konishi and Stolz, for example, show how the ideas of egalitarian cooperatism developed by prewar intellectuals were put into practice in rural communities in

7 The total population as of 1 October 2014 was 100,085, and had declined slightly over the past decade: at the beginning of April 2005 it was 101,393; see Saku-shi no jinkō dēta: 5sai kaikyū betsu, www.city.saku.nagano.jp/shisei/profile/tokei/jinkodata02.html. Accessed 6 April 2015.

8 In 2013, 26.6 per cent of Saku City's population was aged over 65, up from 23.7 per cent in 2005; see Saku-shi no jinkō dēta. 
Hokkaido. ${ }^{9}$ But there are several features that seem to have made Saku and the surrounding areas of Nagano Prefecture particularly fertile ground for nurturing such ideas.

Though a large proportion of the region's pre-Meiji population were poor peasant farmers, the Shinshū area (to use the archaic but still popular name for Nagano) had a relatively high level of education. Divided into a multitude of small domains, it also contained an exceptionally large number of the 'temple schools' (teragoya 寺小屋) that provided education for commoners in the Tokugawa Era. ${ }^{10}$ As Japan opened new trading links to the rest of the world from the mid-19th century onward, the local silk industry flourished, bringing social change and new ideas to the region. Shinshū activists played an important part in the popular rights movement (jiyz minken undō 自由民権運動) of the 1880s, many of them placing particular hope in the role of school education as the path to a freer and more equitable society. ${ }^{11}$

Rather than tracing the history of one particular intellectual group, this chapter takes Saku and its surrounding region as a site for exploring how various streams of thought came together and intermingled in a specific place, and how the legacies of this confluence are still at work in the 21 st century. The focus on place directs attention towards the ordinary people who took up and developed ideas propagated by their better known literary and intellectual contemporaries, and helps us to see how ideas and social action are interwoven. Ideas, of course, are not objects handed on intact from generation to generation like material heirlooms. They are communicated from person to person and from group to group in fluid, partial and mercurial ways. Concepts and theories are reinterpretedsometimes creatively misunderstood - and shaped by changing spatial and temporal circumstances. Diverse intellectual currents come together, colliding and sparking in unexpected ways. Ideas not only influence action but are also themselves the product of action and lived experience. The confluence of ideas and action that has shaped and been shaped by local communities in the Saku region is, I think, particularly worth

9 See Chapter One; also Stolz, Bad Water, Chapter 5.

10 Sakaguchi Mitsukuni, “Ni-yon jiken” to Nagano ken kyōiku: "Kyōiku ken Nagano" ni shūshifu o utta "Ni-yon danatsu jiken"' [The '2.4 Incident' and Education in Nagano Prefecture: The '2.4 Repression Incident' which Put a Full-Stop to Nagano's Role as 'Education Prefecture'], Heiwa to teshigoto [Peace and Handicrafts], 18 (July 2013): 144-61 (citation from pp. 145-6).

11 See Shinshū no Minken Hyakunen Jikkō Iinkai ed., Shinshü minken undōshi [A History of the People’s Rights Movement in Shinshū] (Nagano City: Ginga Shobō, 1981). 
recovering in the contemporary Japanese political environment, where formal national politics seems devoid of lively debate between alternative visions of the future, and where rising nationalism fuels conflict between Japan and its neighbours.

\section{Kobayashi Tatsue and the Legacy of the New Village and White Birch Teachers}

The origins of the social visions at work in Mochizuki, Motai and other parts of Saku City today can be traced to the activities of a group of residents - most of them local school teachers-who were inspired by the writings of the White Birch Group, but who put those ideas to work in distinctive ways. One central figure was Kobayashi Tatsue, the son of a farmer from Kyōwa Village (now part of Saku City), who was born in 1896 and had entered of Nagano Prefectural Teacher Training College in 1914. Many years later, Kobayashi would recall the moment in 1916 when he first encountered the ideas of the White Birch Group as he browsed the shelves of the college library. There he came upon a 700-page magnum opus by Yanagi Sōetsu—a study by Yanagi of the life and works of the English poet, artist and visionary William Blake—and his life was transformed. ${ }^{12}$

Fascinated by the humanism and respect for life that he found in Yanagi's interpretation of Blake, Kobayashi began reading the work of Yanagi's White Birch associates-Arishima Takeo, Shiga Naoya and Mushanokōji Saneatsu-and soon joined a local reading group who shared his enthusiasm for the White Birch philosophies. ${ }^{13}$ For young teachers like Kobayashi, the ideas of the White Birch Group were not just philosophical and aesthetic visions; they pointed to practical education methods radically at odds with the school curriculum imposed by the government.

The modernising Japanese state had created an effective system of universal schooling based on standardised texts, rote learning and substantial doses of nationalism. But the spread of education and the introduction

12 Kobayashi Tatsue, “'Shirakaba” no koro' [The Time of 'White Birch'], in Kobayashi Tatsue no Hon Henshū Iinkai ed., Heiwa to teshigoto: Kobayashi Tatsue 104-sai no tabi [Peace and Handicrafts: The 104-year Journey of Kobayashi Tatsue] (Tokyo: Fukinotō Shobō, 2001), 16-26.

13 ibid., 16-18. 
of foreign ideas brought with them trends that alarmed Japan's rulers. The writings of European anarchists, socialists, pacifists and individualists found their way across Japan's borders alongside the scientific, technical, economic and legal texts needed to advance the nation's place in the global order. The response of the state education system to these undesirable influences was to reinforce the emphasis on discipline, patriotism and self-sacrifice. When Kobayashi entered teachers training college, the ethics (shüshin 修身) texts used in primary schools had recently been revised to place greater emphasis on loyalty to the nation. ${ }^{14}$

All this was anathema to the 'White Birch teachers' (Shirakaba-ha Kyoin 白樺派教員), as Kobayashi and his fellow students and young educators in Nagano Prefecture called themselves. Their readings of Ruskin, Walt Whitman, Romain Rolland, Mushanokōji Saneatsu and others had left them with a profound belief in 'personalist education' (jinkakushugi kyoiku 人格主義教育), whose core principles were to 'nurture the self, respect individuality, love beauty and seek peace. ${ }^{15}$ The White Birch teachers organised reading groups and from 1919 to 1921 published their own journal Chijo (地上). They attended lectures by Yanagi Sōetsu (with whom Kobayashi Tatsue established a lifelong friendship), Mushanokōji Saneatsu and others. Kobayashi Tatsue was also one of the first White Birch teachers to embark on the long journey southwards to the wilds of northern Kyushu-for some, the longest journey they had ever undertaken — to live and work in Mushanokōji Saneatsu's New Village.

Against the background of rapid Japanese industrialisation and urbanisation, Mushanokōji Saneatsu had conceived of the New Village as a quasi-Tolstoyan farm community where work and wealth would be fairly distributed, and where all would participate equally in manual and intellectual labour, and take part in communal decisionmaking. The original New Village was created by 16 pioneers, including Mushanokōji and his wife, in the Hyūga district of Kyushu in 1918, though Mushanokōji himself retreated to the more familiar world of urban society in the mid-1920s, and in 1939 almost the entire community

14 Byron K. Marshall, Learning to be Modern: Japanese Political Discourse on Education (Boulder, CO: Westview Press, 1994), 107.

15 Yoshikawa Tōru, 'Heiwa to teshigoto o kataritsuzuketa kyōikusha Kobayashi Tatsue' [Kobayashi Tatsue, the Educator Who Kept on Speaking of Peace and Handicrafts], in Saku no Senjin Kentō Iinkai / Saku-Shi Kyōiku Iinkai ed., Saku no senjin - kentō jigyō [Saku Pioneers: An Investigative Project] (Saku-Shi: Saku-Shi Bunka Jigyōka, 2012), 26-7; see also Sakaguchi, “"Ni-yon jiken”, 148. 
moved to Moroyama in Saitama Prefecture, where it still exists today. ${ }^{16}$ The New Village was not a rejection of modernity or internationalism; on the contrary, Mushanokōji advocated scientific and technological development as a means to lighten the burden of human labour, and believed that people should become fluent 'not only in their own language but also in the world language' (by which he meant Esperanto). ${ }^{17}$ But the village aimed to be the seed bed of a radically different version of modernity where 'all the world's human beings would fulfil the will of Heaven, and the self which dwells within each individual would be enabled to grow to the full'. ${ }^{18}$ As well as its permanent residents, the village attracted many short-term residents and visitors, and Kobayashi Tatsue proved to be one of these. He joined the village soon after its establishment in 1918, which was also the year of his graduation from college, but soon after arriving there he became seriously ill and had to return home to Nagano Prefecture. ${ }^{19}$ As a result, he probably did not meet the prominent Chinese intellectual Zhou Zuoren (brother of the even more famous Lu Xun), who arrived in the New Village for a visit there in the summer of 1919. But Zhou's arrival symbolises yet another way in which the ripples of the White Birch movement spread out from its small group of founders to resonate in complex ways across Japan and East Asia, initiating the process of diffusion traced by Ou Ning in Chapter Two.

Meanwhile, Kobayashi had come home to a region in turmoil; for his fellow White Birch teachers had begun to put their ideas into action in their Nagano Prefecture classroom. Their aims-'to nurture the self, respect individuality, love beauty and seek peace-inevitably soon fell foul of a state education system that emphasised obedience, discipline and loyalty to nation and empire. ${ }^{20}$ In 1919 , at a school in the mountain village of Togura (now part of Chikuma City), a group of White Birch teachers transformed the curriculum, replacing the official ethics textbooks with readings from works like Tolstoy's Ivan the Fool and Romain Rolland's Jean-Christophe. In place of the officially prescribed glorification of the

16 Mushanokōji Saneatsu, Atarashiki mura no sōzō [Imagining the New Village] (Tokyo: Fuzanbō, 1977).

17 Mushakoji, Saneatsu, Atarashiki mura no seikatsu [Life in the New Village] (Tokyo: Shinchōsha, 1969), 24.

18 Kobayashi Tatsue, 'Ko Mushinokōji Saneatsu shi to Shinshū' [Mushanokōji Saneatsu and Shinshū], in Kobayashi Tatsue no Hon Henshū Iinkai ed., Heiwa to teshigoto, 34-7; quotation from p. 36.

19 Kobayashi Tatsue no Hon Henshū Iinkai, 'Kobayashi Tatsue 104-sai no ayumi' [The 104-year Trajectory of Kobayashi Tatsue], in Kobayashi Tatsue no Hon Henshū Iinkai ed., Heiwa to teshigoto, 266-9; Yoshikawa, 'Heiwa to teshigoto'.

20 Yohsikawa, 'Heiwa to teshigoto'; Sakaguchi, “"Ni-yon jiken”'. 
imperial line and the Japanese military, the White Birch teachers promoted pacifism and criticised Japan's colonial expansion into Korea. Questions were soon raised in the Prefectural Assembly, and the activities of the Togura reformers were crushed. Two teachers were dismissed, while others were temporarily suspended, demoted or transferred. ${ }^{21}$

But some persisted. Kobayashi Tatsue's close friend Nakatani Isao was one of those who took part in the reform attempt and was transferred to another school in the village of Yamato (now part of Matsumoto City) following the Togura Incident. Nakatani, a passionate and popular teacher, continued to put his ideas into practice in quiet ways, taking his pupils for long nature walks and contributing the White Birch teachers' journal Chijo. But another purge soon followed. This time, the teachers' main offence was to celebrate Christmas with a school performance of Mushanokōji's dramatised and mildly subversive reworking of the Japanese folktale 'The Old Man who Made Trees Blossom' (Hanasaku Jijii 花咲爺). Nakatani was dismissed from his teaching position, sank into deep depression and died soon after at the age of $25 .{ }^{22}$

Kobayashi Tatsue himself was not directly caught up in these events, but he was profoundly affected by them. From then on, as a White Birch teacher, he would find his life subjected to intense scrutiny by the education authorities. In an atmosphere of growing repression, he tried to keep his ideals alive in inconspicuous ways, through organising public lectures and other events centred on the ideas of the White Birch Group, and by collecting and promoting local folk art. But he and other likeminded teachers faced continual battles with the education authorities, and were repeatedly transferred from one school to the next in an effort to limit their influence in the classroom. ${ }^{23}$ In early 1933, a further wave of repression resulted in the arrest of over 600 people, mostly in Nagano Prefecture, under the 'Peace Preservation Law' (Chian Iji Hō 治安 維持法) of 1925. About one-third of those rounded up were teachers who were regarded as having expressed radical views. Many of those who avoided arrest were cowed into silence by the threat of dismissal and

21 Sakaguchi, “"Ni-yon jiken”, 149; also Kobayashi, “"Shirakaba” no koro', 22-3.

22 Kobayashi, "“Shirakaba” no koro', 23-24.

23 Yoshikawa, 'Heiwa to teshigoto', 26. 
imprisonment. Among them was Kobayashi, whose sense of remorse at his failure to speak out against the political repression of the 1930s became a major impetus behind his postwar social activism. ${ }^{24}$

From one point of view, there can be no doubt that the White Birch education movement in Nagano failed. Its liberal and anti-war sentiments were unable to withstand the rising tide of militarism, and by the late 1930s the group's members had been scattered and silenced. As a practical step towards a new society, Mushanokōji's New Village, too, can easily be dismissed as a failure. Its founder dreamed of new villages sprouting spontaneously all over Japan, and so transforming society from below; but this did not happen, and in retrospect it seems clear that there was never any prospect of its happening. Yet the New Village had another, less tangible, significance: it was a symbol that provoked people in many places to debate and rethink the possibilities of rural life. And the fact that there was at least one real New Village in existence made the symbol much more powerful than it would have been had it merely been a utopia described on paper. That surely is one reason why the echoes of this century-old 'failed' experiment still reverberates in Bishan, Mochizuki and many other places today.

Judgments of historical success and failure are partly a matter of time. The rise of militarism, the slide into war and the suppression of the White Birch teachers were not the end of the story. Kobayashi Tatsue's life spanned the entire 20th century, and (in evolving forms) carried the ideas of early 20th-century humanism into the 21 st century. Shortly before his 100th birthday in 1996, his friends and supporters created a small meeting place and museum, the Kobayashi Tatsue Peace and Handicraft Folk Arts Hall, perched on a hilltop overlooking Mochizuki, to house the teacher's large collection of craft objects. This has become a focus for ongoing local movements to promote social education, sustainable development and local peace initiatives. 


\section{Social Education and Visions of a Local Future}

Looking back at his youthful ideals from the vantage point of postwar Japan, Kobayashi Tatsue wrote:

the consistent element in the White Birch group was the notion of 'cultivating the self' Japan's defeat has created a painful awareness of the importance of building individuality on firm foundations. To lack your own beliefs and perceptions, and to follow the herd wherever others lead you, is the source of all evil and misery. ${ }^{25}$

The failure of the White Birch intellectuals and other Japanese humanists actively to resist militarism and imperial expansionism has often been emphasised, ${ }^{26}$ but what is rarely noted is the deep sense of guilt about that failure that impelled some of them to embark on postwar social activism. Kobayashi Tatsue was one of those people. Haunted by memories of his own inability to speak out against the arrests of his colleagues, he devoted his postwar life to promoting their ideals-the ideals of peace and of people's art—with consequences that are still being felt in his home region today. ${ }^{27}$

As a schoolteacher, writer and social activist in the 1950s, Kobayashi won support from the local education committee to create a folk craft collection that was exhibited and used as a focus for events such as lectures by Yanagi Sōetsu and the British Mingei movement potter Bernard Leach. He studied and practised traditional textile dyeing techniques, and wrote and published widely on the importance of nurturing human creativity and on peace and nuclear disarmament. He participated in a local protest movement against plans to establish a US military training base on the slopes of nearby Mt Asama, and in 1981, at the age of 85, launched a successful local journal, Kyōwa Tsūshin (Kyōwa News 協和通信), which he continued to edit and publish for the next 10 years. The title was a telling play on words: Kyowwa means 'harmony' or 'oneness', but also happens to be name of the village where Kobayashi was born and spent the last years of his life. ${ }^{28}$

25 Kobayashi, “'Shirakaba” no koro', 17.

26 See, for example, Aso, 'Mediating the Masses'.

27 Yoshikawa Tōru, 'Kankō ni atatte' [On the Occasion of Publication], in Kobayashi Tatsue no Hon Henshū Iinkai ed., Heiwa to teshigoto, 1-8, citation from p. 4.

28 Kobayashi Tatsue no Hon Henshū Iinkai, 'Kobayashi Tatsue 104-sai no ayumi', 268-9. 
Like the philosophies of his White Birch predecessors, Kobayashi's idealist enthusiasm for folk arts and peace can be (and sometimes has been) criticised as naive and impractical. But its tangible impact is vividly described by Yoshikawa Tōru, a teacher and activist who first arrived in Mochizuki as a young graduate from Tokyo in the early 1960s and has lived there ever since. Amongst the postwar generation who came in contact with Kobayashi and his fellow former White Birch teachers, Yoshikawa writes:

There were those who said 'I understand the theory all right, but I just can't live the way our teacher does'. And those who studied with him often said, 'I can't follow what he's saying'. I have to say that I sometimes felt the same way myself. But the people who had been taught by the White Birch Teachers as children, even for a short time, were influenced in a way that affected the rest of their lives. In old age they were still talking about their recollections of that time with such enjoyment that, seeing their expressions, I would wonder what the secret of those teachers was. ${ }^{29}$

In the postwar era, a web of local human interaction brought ideas inherited from the White Birch and craft movements into contact with new forces of agrarian and peace protest. The allied occupation of Japan resulted in the liberalisation of education, and in land reform that greatly improved the lives of farmers. As the Japanese economy began to revive from the devastation of war, a wave of enthusiasm for grassroots education, self-improvement and democratisation was expressed in the appearance all over the country of 'study circles' (säkuru サークル), where farmers, factory workers, housewives and others studied topics such as local history, political ideas, arts and literature. 'Social education' (shakai $k y \bar{o} i k u$ 社会教育) became the buzzword of the era.

In rural Nagano Prefecture, a focus for this postwar passion for selfimprovement was provided by the Seinendan (Youth Groups 青年団) to which most young villagers, male and female, belonged. ${ }^{30}$ Before and during the Pacific War, the rural youth groups were generally seen as hotbeds of nationalism, and became a central element of the militarising state's pyramid of social control. ${ }^{31}$ But in parts of postwar Japan, the Seinendan came to play a very different role. In its early postwar years, the

29 Yoshikawa, 'Kankō ni atatte', 2.

30 Interview with Shimizu Noriko, Shimizu Kiyoshi and Itō Kimiko, Kyōwa, 28 May 2015.

31 Mikiso Hane, Peasants, Rebels, Women and Outcasts: The Underside of Modern Japan (Lanham, NJ: Rowman and Littlefield, 2003), 61-2; Sally Ann Hastings, Neighbourhood and Nation in Japan, 1905-1937 (Pittsburgh, PA: University of Pittsburgh Press, 1995), 109-22. 
rural grassroots enthusiasm for study and self-improvement was driven by a passion for agricultural modernisation. New farm machinery began to appear in local fields, and villagers immersed themselves in the latest American-inspired manuals on farm management. But by the late 1950s, a more critical element was also entering the debates that took place in night-time gatherings in the village halls of Saku and surrounding areasan element that reflected the changing face of Japanese farming. The rural young were not immune from the critical social ideas that, by the 1960s, were radicalising Japan's students and urban youth. In some areas of Japan Seinendan members, inspired partly by left-of-centre intellectuals who moved to the countryside to disseminate their social ideas, launched music and drama groups, discussed visions of a new Japan, and participated in strikes for higher produce prices and protests against environmentally damaging development projects.

Following the signing of the San Francisco Peace Treaty and of the Security Treaty (commonly known as Ampō) with the US in 1951, the Japanese Government entered into negotiations with the US on military security assistance (MSA) from America to Japan. The agreement, finally signed in 1954, included a somewhat convoluted arrangement under which Japan would buy surplus agricultural produce from the US, and in return, the US would pay back part of the proceeds to the Japanese Government as aid for heavy industrial development (including support for Japan's reviving armaments industry). ${ }^{32}$ The inflow of cheap US agricultural produce into Japan dealt a serious blow to Japanese farmers, who suddenly found the prices for their wheat or milk undercut by dumped US goods. In 1960, frustration at the MSA flared up into a strike and protest demonstrations by Japanese dairy farmers at the dumping of US milk powder on the Japanese market. Farmers from Mochizuki and other parts of Saku City were key figures in the protest - the first strike by farmers in Japanese history. ${ }^{33}$

Criticism of the MSA agreement also flowed into rising opposition to the introduction of a revised Security Treaty, and by 1960 some young farmers were explicitly linking their own struggles to stay on the land with problems of the Japan-US military alliance and with a broader critique of

32 See John L. Weste, 'Salvation from Without: Mutual Security Assistance and the MilitaryIndustrial Lobby in Post-War Japan' in Stephen S. Large ed., Showa Japan: Political, Economic and Social History, 1926-1989, vol. 3 (London and New York: Routledge, 1998), 24-43, particularly p. 35.

33 Interview with Kobayashi Tetsuo, Saku City, 16 May 2015; interview with Itō Morihisa, Mochizuki, 29 May 2015. 
the trajectory of Japanese industrialisation. ${ }^{34}$ One farmer who joined the Mochizuki Youth Group in 1955 recalls how in 1960 he and his fellow members would get up before dawn and ride their bicycles over the rough rural roads to the nearest railway station, over 20 kilometres away, to catch the train to Tokyo and take part in the mass anti-Ampō demonstrations that precipitated the resignation of Prime Minister Kishi Nobusuke. ${ }^{35}$

These activities made local people more aware of a need to understand the world they lived in. A group of young farmers who had been involved in the milk strike therefore lobbied for the creation of a social education centre in Mochizuki. The man appointed to run the centre, Yoshikawa Tōru, was a newcomer to the region-a recent graduate from Tokyo who threw himself wholeheartedly into the task, working closely with local elder Kobayashi Tatsue. During the early 1960s, study circles in and around Mochizuki were meeting almost every evening, discussing social issues like the Cold War, industrialisation and the growing outflow of young people to the expanding metropolitan areas. Here, themes from the prewar White Birch philosophies reemerged in new form: the value of peace; the search for human creativity; respect for craft traditions; concern at the corrosive effects of corporate capitalism on society and community. The study groups met in the village halls (kominkan 公民館) that existed in almost every hamlet, and participants ate, drank and talked deep into the night around the charcoal braziers that filled the halls with their thick haze of smoke. ${ }^{36}$ Arts and self-expression, in the form of choirs and drama groups, went hand-in-hand with heated debates on political and social ideas. Kobayashi Tatsue, as director of the village hall and a frequent speaker at their classes, influenced the artistic as well as the intellectual lives of the young farmer-students, helping them to raise money to buy books and even to acquire a record player and records-still luxuries in the village at that time. ${ }^{37}$

34 Kobayashi Setsuo, 'Nagano Ken chiiki jūmin daigaku ni itaru zenshiteki haikei to shiteki kansō: Sengo no nōbunkyō no undō kara chiiki jūmin daigaku ni itaru made’ [Early Historical Background and Personal Impressions of the Nagano Prefectural Residents' University: From the Postwar Nōbunkyō Movement to the Regional Residents' University], in Nagano Ken Chiiki Jūmin Daigaku Gakushū Undōshi Henshū Iinkai ed., Tagayashi, manabi, kangaeru: Sengo Nagano ken gakushū undōshi [Tilling, Learning, Thinking: The Postwar Nagano Prefecture Educational Movement] vol. 1 (Nagano City: Nagano Ken Chiiki Jūmin Daigaku, 2013), 43-159.

35 Interview with Shimizu Noriko, Shimizu Kiyoshi and Itō Kimiko, Kyōwa, 28 May 2015.

36 Interview with Yoshikawa Tōru, Mochizuki, 1 July 2013.

37 Interview with Shimizu Noriko, Shimizu Kiyoshi and Itō Kimiko, Kyōwa, 28 May 2015. 
The overtly critical political tone of Mochizuki social education alarmed more conservative members of the local government. In 1970, following a workshop that questioned local government agricultural policy, the local authorities moved to cut the financial support they had been giving to the social education programs, and only energetic protests by students managed to save Yoshikawa Tōru's teaching position. But the Japan of the 1960s was a very different place from the Japan of the 1910s and 1920s, when the activities of the White Birch teachers had so easily been crushed by the heavy hand of the state. Protests by students and their supporters succeeded in not only preserving but even expanding the Mochizuki social education program, ${ }^{38}$ and the experience of protest itself became part of the educational experience. Itō Morihisa, the son of a local dairy farmer and an eager participant in the social education classes of the 1960s, recalls:

Mr Yoshikawa had an accordion, and we would have musical gatherings, but at the same time we could also learn about social issues and so forth together. I think that was the real basis of our ongoing movement. I was head of the local Seinendan at the time, and it was through involvement in the struggle to save Mr Yoshikawa's position as the social education director that I developed my own view of the world and a sense of my place in society. ${ }^{39}$

The central message of the social education movement was 'think for yourself'. Participants were encouraged not to accept the dictates of government, but to create their own visions for the future of their region. ${ }^{40}$ And as high-tech industrialisation transformed the face of Japan, this was to lead to new struggles both with and within the formal structures of local government.

\section{The Body Politic-Rural Medicine and Social Visions in Saku Central Hospital}

Meanwhile, the local world of grassroots ideas and activism was being influenced by other currents of thought that came from cooperatism and social medicine. The focal point from which these ideas radiated was Saku

38 Interview with Itō Morihisa, Mochizuki, 29 May 2015.

39 Interview with Itō Morihisa, Mochizuki, 1 July 2013.

40 Interview with Yoshikawa Tōru, Mochizuki, 1 July 2013. 
Central Hospital (Saku Sögō Byōin 佐久総合病院), founded at the height of the Asia-Pacific War. The hospital first opened its doors in January 1944 , at a time when the overriding aim of state medical policy was 'to secure "human resources" - in other words soldiers for the battlefront and workers for wartime industry — in order to pursue of the war effort'. ${ }^{41}$ But it was also part of Japan's extensive cooperative movement, which, as Tetsuo Najita persuasively argued, has played a central though long-neglected role in economic and social development. As Sho Konishi observes in Chapter One, cooperatively run 'people's hospitals' (heimin byoin 平民病 院) had formed a crucial element of the cooperatist/anarchist movements of the 1910s and 1920s.

Like a number of other medical centres throughout the country, Saku Central Hospital was an offshoot of a local agricultural cooperative. Its second director, appointed six months before Japan's defeat in war, was physician Wataksuki Toshikazu (1910-2006), who had been a member of a prewar Marxist study group at the University of Tokyo. Wakatsuki had been arrested twice for his political views, and had spent a year in prison shortly before his appointment to Saku Central Hospital. He was encouraged by a mentor to take a post in this rural mountain community in the hope that this would help him to evade the unwelcome attentions of the thought police. To obtain release from prison, Wakatsuki had been induced to sign a statement of 'conversion' (tenkō) renouncing his subversive views (an act about which he expressed lifelong regret), but the influence of his early encounters with Marxist, socialist and humanist ideas continued to influence his thought and medical practice in profound ways. ${ }^{42}$ Following Japan's defeat, these ideas interacted with the longing for a better life felt by many local residents in Saku and surrounding regions as they recovered from the disasters of war and faced the massive tasks of rebuilding their community. From this interaction, Saku Central Hospital emerged as a pioneer of rural social medicine within Japan and beyond.

In the second half of the 1940s, the hospital confronted a massive health crisis. Malnutrition and diseases like tuberculosis were rife. Thousands of displaced people were returning to the local area from Japan's lost empire.

41 'Saku Byōinshi' Sakusei Iinkai ed., Saku Byöinshi [A History of Saku Hospital] (Tokyo: Keiso Shobō, 1999), 33.

42 Kawakami Takeshi, 'Wakatsuki Toshikazu sensei no shigoto to seishin' [The Work and Spirit of Dr Wakatsuki Toshikazu], Bunkaren jōhö [Bunkaren Report], 344 (2006): 33-6; Wakatsuki Toshikazu, Nöson iryo ni kaketa 30-nen [Thirty Years Spent in Rural Medicine] (Tokyo: Ie no Hikari Kyōkai, 1976), 34-5. 
Medicines and medical equipment were in desperately short supply. In these conditions, the Saku medical staff strongly resisted proposals to transfer their hospital to the control of government, and insisted that it should remain part of the cooperative system, even though they fought running political battles with some of the more conservative figures in the local agricultural coop ${ }^{43}$.

The hospital, whose slogan was (and still is) 'Together with the Farmers' (Nömin to tomo $n i$ 農民とともに), was literally sustained by the support of the local farm community, particularly after a fire destroyed much of the hospital compound in 1949. The funds for reconstruction were raised by local residents, and local farmers and the hospital together worked out ways to cooperate in linking hospital treatment to community health. For example, it soon became clear that the recovery of patients discharged from hospital was hampered by poor nutrition, so a system was devised where farmers provided vegetables and other produce, and hospital staff cooked these into nutritious meals to be delivered to recuperating patients. Very unusually for a Japanese hospital at that time, Saku Central encouraged patients' relatives to be present during operations. ${ }^{44}$ The hospital also evolved into the focus of a series of patient self-help associations. The members of the first club, made up of patients suffering from the crippling and (in the 1940s) incurable Pott's Disease (tuberculosis of the spine), were soon producing their own journalSebone 背骨 (Backbone) — which published both medical information on advances in treatment and articles by patients and their families. ${ }^{45}$

So hospital staff, patients and local residents developed a view of social medicine that integrated hospital and community, transforming the conventional image of the role of a hospital as an island of technical expertise in a sea of potential patients. 'Health' from this point of view, is not just a matter of the treatment of disease, but a matter of life as a whole. Saku Central Hospital became the site of a monthly informal discussion group including medical staff, young farmers and others, and ranging over a wide spectrum of social and political issues. The hospital drama group toured villages presenting plays on problems of health, welfare and society (often in a lighthearted, seriocomic style). Wakatsuki Toshikazu described

\footnotetext{
43 'Saku Byōinshi' Sakusei Iinkai, Saku Byōinshi, 50.

44 ibid., 36-8 and 41-2.

45 ibid., 62-3; see also Honda Toru, 'Health Equity: Japan's Post-War Strides towards Universal Health Coverage from a Grassroots Perspective', Global Health Check (11 November 2014), www. globalhealthcheck.org. Accessed 17 January 2015.
} 
the interaction as a form of mutual education: hospital staff passed on knowledge about health issues and at the same time learnt about the lives of their patients in ways that 'humanised' their medical practice. ${ }^{46}$ When Saku Central, known to local conservatives as 'the Red Hospital', was threatened by the allied occupation's purge of suspected 'communists', local residents rallied to its support, and some 45,000 of them signed a petition to defend their hospital.

At a personal level, Wakatsuki and his medical staff formed close relationships with Kobayashi Tatsue, Yoshikawa Tōru and others involved in the social education movement, and after Wakatsuki's death in 2006, younger doctors whom he trained and influenced have continued his tradition of social activism. The hospital's study circles interacted with the study circles of the social education movement, and participants in both took part in a series of protests that profoundly influenced the nature of local economic and social development from the 1970s onward.

\section{The Miyamoto School and Endogenous Development}

It is a scorching August afternoon, and a group of several dozen people are holding their regular gathering in the Kobayashi Tatsue Peace and Handicraft Folk Arts Hall. The speakers include Yoshikawa Tōru and his former student Itō Morihisa-a farmer and social reformer who has also served as a member of the local government assembly. They are joined by Irohira Tetsurō, a doctor from Saku Central Hospital; and Miyamoto Kenichi, from whom the group takes its name. This is a gathering of the Shinshū Miyamoto School (Shinshü Miyamoto Juku 信州宮本塾), a discussion circle that has been meeting on a regular basis for over two decades to explore visions of sustainable and endogenous development for their region. On tables and shelves all around the room stand rows of the thickly glazed vases and blue patterned plates collected by Kobayashi Tatsue to celebrate the simple beauty of folk crafts. An old weaving loom fills one corner of the hall, and photos of Kobayashi and his heroes, among them Yanagi Sōetsu, Gandhi and Roman Rolland, look down, benign but unsmiling, on the participants.

46 Wakatsuki Toshikazu, Nōson iryo ni kaketa 30-nen; Wakatsuki Toshikazu, Acceptance speech for the 1976 Ramon Magsaysay Award, 1976, www.rmaf.org.ph/newrmaf/main/awardees/awardee/ profile/221. Accessed 18 January 2015. 


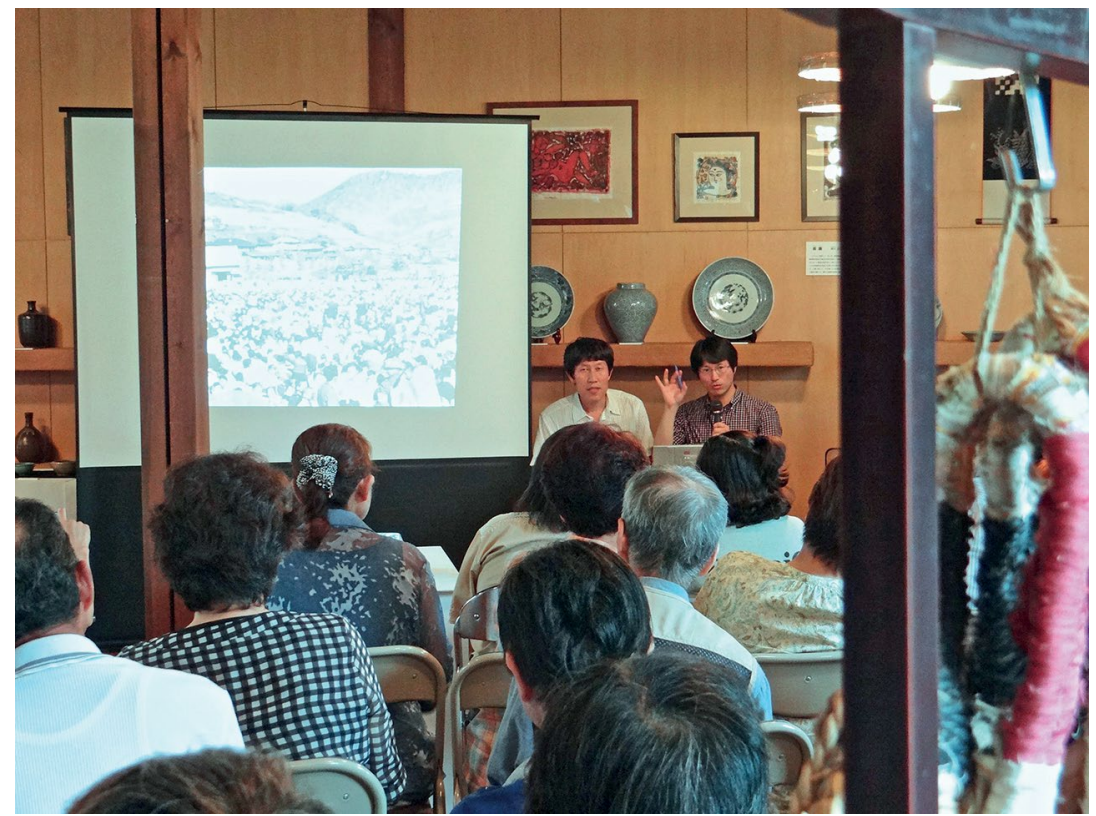

Figure 3: A meeting of the Shinshū Miyamoto School.

Source: Tessa Morris-Suzuki.

The Miyamoto School emerged from the social education experiments of the 1960s, 1970s and 1980s, and from the protest movements that these precipitated. By the 1980s, urban drift and the decline and ageing of rural populations were becoming major challenges for regions like Saku. In an effort to stave off economic decline, the local government put forward a series of development proposals centred on attracting large metropolitan firms to invest in the area. These included plans for golf courses, for industrial waste disposal plants, and (in the early 1990s) for a giant off-course betting centre that, it was hoped, would attract punters from all over eastern Japan. The farmers who had taken part in the social education movement, many of whom were now entering middle age, saw the grand designs of the local authorities as threatening the natural and social environment of their region and offering few if any real benefits to local people. Their response was to question the plans both from outside and inside formal politics.

A series of small protest movements sprang up in towns and villages across the region. In 1994, for example, a former 1960s member of the Mochizuki Seinendan, who had just retired from a career in local administration, joined with an elderly woman resident to lead protests 
against plans to build a potentially highly polluting industrial waste dump and incinerator in the mountains close to Mochizuki. This was the start of a 10-year struggle, which ultimately ended in victory for the protestors in the spring of $2003 .{ }^{47}$ Yoshikawa Tōru, Itō Morihisa and others, meanwhile, were helping to organise public demonstrations against the off-course betting centre scheme, which also led to the scheme being abandoned. ${ }^{48}$ But the very success of their opposition left the protestors with a challenge: to devise alternative strategies that could at least do something to resolve the real social and economic problems confronting their region. They were not conservatives, simply seeking to hold back the encroaching tide of change. But finding coherent and persuasive alternative forms of change that fitted the values they espoused was no easy matter. It was here that the advice of Miyamoto Kenichi proved crucial.

Miyamoto's origins lie outside the Saku region. Born in colonial Taipei in 1930, he spent much of his career teaching economics at Osaka City University. During the 1970s and 1980s, Miyamoto became internationally known both as an anti-pollution activist taking part in the movements discussed by Simon Avenell in Chapter Four, and as a theorist of the relationship between economic structure and environmental crisis. Miyamoto's work draws on but adapts Marxist economic theory to emphasise the role of the state and of state infrastructure policy as a cause of ecological destruction, and highlights the vital role of grassroots action in preserving the environment. ${ }^{49}$ By the late 1980s, he was turning his attention particularly to development from below, or endogenous development (naihatsuteki hatten 内発的発展)—a concept whose key elements are that local people devise and manage plans for their community's future, drawing on local resources, and that the value added

47 Asahi Kensetsu no shōkyakuro ni hantai suru taisaku iinkai, Asahi Kensetsu no noyaki, sanpai shökyakuro ni hantai suru jümin no kiroku [A Record of the Residents' Movement against Asahi Construction's Open-Air Burning and Industrial Waste Incinerator] (Mochizuki: Asahi Kensetsu no Shōkyakuro ni Hantai suru Taisaku Iinkai, 2009); interview with Iijima Katsuhiko, Mochizuki, 26 May 2015.

48 Interview with Yoshikawa Tōru, Mochizuki, 1 July 2013.

49 See Simon Avenell, Making Japanese Citizens: Civil Society and the Mythology of the Shimin in Postwar Japan (Berkeley and London: University of California Press, 2010), 153-5; Tessa MorrisSuzuki, A History of Japanese Economic Thought (London: Routledge, 1989), 151-3. 
from development should be returned to the local area. ${ }^{50}$ Miyamoto had become a friend of Saku Central Hospital's rural medicine pioneer Wakatsuki Toshikazu, and was eager to develop closer links to the Saku region so that he and his students could refine their ideas in direct dialogue with small-scale farming communities. His ideas in turn resonated with the emphasis on human creativity and respect for crafts traditions that the former White Birch teachers had passed on to the postwar generation in the Saku region. Miyamoto bought a house in mountains of Saku where he spent extended periods of time, particularly after his retirement from Osaka City University, and from this base became increasingly closely involved in Saku community life.

The Miyamoto School was formed in 1992, as a venue where local people from Mochizuki and the surrounding area could come together to study the principles of endogenous development and to share their ideas for the future of their region with one another and with Miyamoto and other academic experts. The group meets once a month, except in the depth of winter, and has gradually extended its bounds to include participants from a widening area of Nagano Prefecture. Its meetings are not lectures, where outside experts instruct local people on the proper paths of development, but are forums for a sharing of ideas amongst equals. The school has organised field trips to other areas of Japan facing similar economic challenges, and has published two 'Residents' White Papers' (Nōsonhatsu Jūmin Hakusho 農村発住民白書), setting out local projects for endogenous development.

One of the first of these projects for 'development from below' was the launch in 1993 of the Kataribe saké brand. Itō Morihisa joined hands with Motai's 300-year-old brewery, supplying them with special lowchemical farmed rice for this brand, which has become a successful 'export' product, sold to other parts of Japan as well as to locals and visitors to the region. Over the years, the range of local endogenous development schemes has gradually grown. A project was established to help city people start new lives as farmers in the Saku region, with a particular emphasis on organic farming, and this has succeeded in bringing a number of new

50 Miyamoto Kenichi, Kankyō keizaigaku [Environmental Economics] (Tokyo: Iwanami Shoten, 1989); Tanaka Natsuko, 'Chūsankanchi no naihatsuteki hatten to chiikizukuri no nettowāku: KitaSaku gun Mochozuki machi ni okeru chiikizukuri jūmin soshiki no ayumi to kadai' [Endogenous Development in a Mountain District and the Regional Development Network: History and Issues of a Regional Development Citizens' Orgainzation in Mochizuki Town, North Saku District]. Nagano Daigaku kiyō [Annals of Nagano University] 19, no. 1 (1997): 49-61. 
farm families to the district. Itō Morihisa has created an educational program that allows school groups of urban children to stay on his farm and experience agriculture at first-hand. In 2001, a local currency system was launched in the nearby city of Ueda, and its 200-odd members are now engaged in a range of local development and education schemes. An award-winning restaurant serving locally grown soba has been developed by a chef who also continues Kobayashi Tatsue's tradition of researching and preserving local folk crafts. ${ }^{51}$ The network around the Miyamoto School has also maintained its particularly close link to Saku Central Hospital, campaigning for the support and development of its rural medicine model, and creating its own health initiatives, such as support schemes for elderly residents. ${ }^{52}$

Over the years, the Miyamoto School has debated local problems like the Saku City amalgamation, as well as larger national issues such as Japan's postwar pacifist constitution. Today, much interest focuses on nuclear power and the international free-trade negotiations surrounding the Trans-Pacific Partnership. The participants in the school are not adherents of a particular political party or a specific ideology, and there is no party line on these matters, though the principles of endogenous development inform all their discussions. A characteristic of the school, though, is to try to take discussion of problems beyond the purely local framework; to consider, for example, not just how the Trans-Pacific Partnership will affect local farm sales, but also how it affects other parts of Asia, and (as in the case of the MSA and the 1960 Security Treaty renewal) how trade and military issues are interwoven.

\section{The Next Hundred Years}

How do we judge the success or failure of a grassroots movement? If longevity is a mark of success, the residents of Saku surely deserve credit for keeping a lineage of alternative social thought alive for almost a century. Interestingly, they have done this without any enduring institutional structure, but simply through the transmission of ideas and experiences from individual to individual within a fluid and changing

51 Shinshū Miyamoto Juku ed., Nōsonhatsu jūmin hakusho dai-2 shū: Tomo ni ikiru [A Citizens' White Paper Initiated from the Villages, vol. 2: Living Together] (Mochizuki: Shinshū Miyamoto Juku, 2013); interview with Itō Morihisa, Mochizuki, 29 May 2015.

52 Interview with Shimizu Noriko, Shimizu Kiyoshi and Itō Kimiko, Kyōwa, 28 May 2015. 
network of grassroots groups. The ideas they embrace have left tangible traces on the life of the region. Without their existence, it is likely that Saku City would have had more large-scale corporate development projects of the sort promoted by many Japanese local governments in the 1970s and 1980s, and less organic farming and craft-style production, exemplified by local products like Kataribe saké. The rural medicine developed by Wakatsuki and the doctors he trained has also left its mark-the Saku region is widely recognised for the high quality of its health care..$^{53}$

But while a formal political party might judge success by election victories or the fulfilment of its party platform, the aims of the Saku region's endogenous development networks are broad, open-ended and evolving, so assessing their overall achievements is much more difficult. As some problems have been overcome, others have come into focus-issues, for example, of gender and generation. The social education movement of the 1960s and 1970s was overwhelmingly male-dominated. Though women performed large amounts of labour on local farms, agricultural management was largely in the hands of men, as was leadership in social life. In the 1950s and 1960s Seinendan, for example, the convention was that the leader would always be a young man and the deputy a young woman. ${ }^{54}$ Over the past 20 years or so, the social hierarchy has been changing. Many women now play increasingly important parts in the Miyamoto School and endogenous development schemes, among them Tsuru Bunka University professor Tanaka Natsuko, a leading Japanese expert on the cooperative movement; Mochizuki-born editor and publisher Hata Yumiko; and Yoshikawa Tōru's daughter Yūko, who is a member of Saku City Council. But change has been gradual, and there is still surely scope for women's voices to play a greater role in the shaping of the network's ideas. A glance around the room at meetings of the Miyamoto School, as at the gatherings of many grassroots groups in Japan today, reveals an ageing population of participants. There are many grey heads and many backs bent by lives of hard work. This partly reflects the ageing of the Saku population as a whole; but, as Yoshikawa, Itō and other readily acknowledge, engaging the younger generation is a challenge.

Meanwhile, Saku's social alternatives face a mass of larger challenges from the outside world. For the farmers of the district, climate change is not an abstract concept but a reality faced every day, in plants that ripen out

53 See for example Honda, 'Health Equity'.

54 Interview with Shimizu Noriko, Shimizu Kiyoshi and Itō Kimiko, Kyōwa, 28 May 2015. 
of season and monsoon rains that fail to arrive on time. Yet, rather than focusing on the huge challenges of global warming and of Japan's pressing need for new and safe sources of energy, the national government's policy is directed above all to a pursuit of national might through ever-deepening economic and military commitment to the US alliance-a policy that raises the defence budget, opens the agricultural market to cheap imports and destabilises East Asian relations in ways that many local people find deeply alarming. Indeed, the political landscape of Japan appears to have undergone a subtle change in recent decades. The metropolitan areas, once the main centres of progressive politics, are now dominated by rightwing local administrations, while in some rural areas growing currents of unease are disrupting the traditional image of the countryside as the backbone of conservative politics.

When the White Birch teachers started their educational experiments in unpromising circumstances a century ago, would they have imagined that their ideas would still be reverberating in the valleys of Saku 100 years later? Did they see themselves as pioneers of a social revolution that would soon sweep the world, or as voices in the wilderness? The story of the legacy that grew from their actions provides an illustration of the quiet ways in which ideas can survive and grow even in sometimes hostile environments. The concepts of humanist schooling and social education, of rural community medicine and endogenous development nurtured over decades in Saku and surrounding regions have relevance, not just for other parts of Japan, but also for many communities worldwide that face similar challenges today. The survival of these ideas against the odds provides at least some hope that they can be sustained, reshaped and reinvigorated over the century to come. 
This text is taken from New Worlds from Below: Informal life politics and grassroots action in twenty-first-century Northeast Asia, edited by Tessa Morris-Suzuki and Eun Jeong Soh, published 2017 by ANU Press, The Australian National University, Canberra, Australia. 